$\begin{array}{lll}\text { ISSN: 2356-4547 (Print), 2721-0006 (Online) } & \begin{array}{l}\text { Article History: } \\ \text { Submitted }\end{array} & : 12 / 08 / 2021 \\ \text { Vol. 8, No. 1, Oktober 2021, (1-26), https://s.id/Man_Raf } & \text { Reviewed } & : 13 / 08 / 2021 \\ \text { Published By: Sekolah Tinggi Teologi Arastamar Bengkulu } & \text { Accepted } & : 04 / 10 / 2021 \\ & \text { Published } & : 31 / 10 / 2021\end{array}$

\title{
HIKMAT DALAM MISI ISRAEL MENURUT ULANGAN 4: 5-8
}

\author{
Paulus Dimas Prabowo ${ }^{1}$ ) \\ Sekolah Tinggi Teologi Injili Indonesia Yogyakarta ${ }^{1}$ \\ *)Email Correspondence:*paul110491@gmail.com
}

\begin{abstract}
The wisdom of Israel is linked to their mission. Another unique thing is that wisdom which is usually associated with divine power, intellect, spirituality, practical skills, and the meaning of life, apparently is also associated with missions for all nations. Israel as God's chosen nation with a royal priesthood carries out a noble task to fulfill His promise to Abraham that his descendants will be a blessing to all tribes. In carrying out these responsibilities, Israel needed wisdom. Through exegesis studies of Deuteronomy 4: 5-8 and supported by literature studies, it can be found that the wisdom of Israel was implemented in obedience to the law of God. From this obedience, the nations will see the quality of their lives, hear their preaching about the LORD and His decrees, and recognize that Israel is a special nation until finally they are expected to give praise to God and even follow Him. This review also reveals the fact that the mission carried out by Israel is either centripetal or centrifugal. The results of this study can also be applied in the missionary task of believers today.

Keywords: Wisdom, mission, Israel

Abstraksi: $\quad$ Hikmat Israel dikaitkan dengan tugas misi. Hal unik lainnya ialah bahwa hikmat yang biasa dikaitkan dengan kuasa ilahi, intelektualitas, spiritualitas, ketrampilan praktis, dan makna hidup, rupanya juga dikaitkan dengan misi bagi segala bangsa. Israel sebagai bangsa pilihan TUHAN yang imamat rajani mengemban tugas mulia guna mewujudkan janji-Nya kepada Abraham bahwa keturunannya akan menjadi berkat bagi segala suku bangsa. Dalam menunaikan tanggung jawabnya tersebut, Israel memerlukan hikmat. Melalui studi eksegesis Ulangan 4: 5-8 dan dengan ditunjang studi literatur, dapat ditemukan bahwa hikmat Israel terimplementasi dalam ketaatan melakukan Taurat TUHAN. Dari ketaatan ini bangsa-bangsa dapat melihat kualitas hidup Israel, mendengar pemberitaan tentang TUHAN dan ketetapan-Nya, serta mengakui bahwa Israel merupakan bangsa istimewa hingga akhirnya diharapkan menaikkan pujian kepada TUHAN bahkan mengikuti-Nya. Ulasan ini turut membuka fakta bahwa misi yang dijalankan oleh Israel adalah secara sentripetal maupun sentrifugal. Hasil penelitian ini pun bisa diterapkan dalam tugas misi orang percaya saat ini.
\end{abstract}

Kata kunci: Hikmat, misi, Israel

\section{PENDAHULUAN}

Topik hikmat telah memantik pembahasan yang begitu luas dan tidak pernah ada habis-habisnya. Penyelidikan terhadap hikmat mewarnai abad-abad yang telah lampau dan terus berlanjut pada hari-hari mendatang. Dalam 
sejarahnya, mulai dari zaman kuno, era filsuf Yunani, hingga era sekarang hikmat telah dikaitkan dengan keilahian, etika, politik, sains, moral, dan makna hidup, yang semuanya berkontribusi untuk kehidupan manusia yang lebih baik. ${ }^{1}$ Terlihat bahwa aspek-aspek kehidupan manusia melibatkan hikmat di dalamnya.

Pembahasan tentang hikmat kian meriah sebab Alkitab, secara khusus Perjanjian Lama, turut mengemuka dan berperan serta. Roh Kudus mengilhami penulis untuk menuliskan topik hikmat di dalamnya. Selama ini telah menggema, bahwa topik tersebut dibahas dalam bagian sastra hikmat seperti Ayub, Amsal, dan Pengkhotbah. Beberapa mazmur, menurut Gunkel, juga terindikasi memuat ajaran hikmat, seperti Mazmur 1, 37, 49, 73, 91, 112, dan $128 .^{2}$ Namun rupanya topik hikmat tidak 'terpenjara' dalam sastra hikmat dan mazmur-mazmur tertentu saja. Kita bisa menemukan jejak-jejaknya di tempat lain yang tak disangka. Para sarjana setuju bahwa materi hikmat merupakan tema universal yang dapat ditemukan di seluruh Perjanjian Lama, baik dalam Hukum, Sejarah, Puisi, maupun Nubuatan. ${ }^{3}$ Artinya, pembahasan topik hikmat bisa lebih luas dari yang selama ini diduga dan karya-karya yang segar tentangnya akan terus lahir.

Akhir-akhir ini telah muncul beberapa karya bertopik hikmat yang dikaitkan dengan aspek-aspek tertentu. Yang pertama adalah tulisan yang berjudul "Pergulatan Hikmat dalam Kitab Pengkhotbah" yang ditulis V. Indra Sanjaya. Hikmat dikaitkan dengan realitas hidup. Tulisan ini menyelidiki perkembangan

1Paul B Baltes dan Jacqui Smith, "The fascination of wisdom: Its nature, ontogeny, and function," Perspectives on psychological science 3, no. 1 (2008): 116, https://doi.org/10.1111\%2Fj.17456916.2008.00062.x.

2 Hermann Gunkel dan Joachim Begrich, Introduction to the Psalms: The Genres of the Religious Lyric of Israel (Macon, Georgia: Mercer University Press, 1998), 295-97.

3 Craig G. Bartholomew dan Ryan P. O'Dowd, Old Testament Wisdom Literature: A Theological Introduction (Downers Grove, IL: InterVarsity Press, 2011), 4.

4 V Indra Sanjaya, "Pergulatan Hikmat dalam Kitab Pengkhotbah," Jurnal Orientasi Baru 19, no. 2 (2010): 109, https://e-journal.usd.ac.id/index.php/job/article/view/1375/1117. 
tradisi hikmat dalam Alkitab melalui perbandingan Qohelet (Pengkhotbah) dengan Amsal yang menunjukkan perkembangan gagasan yang signifikan, dimana hukum retribusi sebagai kearifan tradisional yang diwakili Amsal tidak berfungsi di dalam Pengkhotbah. Dalam temuannya, nampak bahwa Qohelet melihat hukum retribusi (sebab-akibat) menemui banyak kekecualian dalam kehidupan yang lain, dimana orang baik dan jahat sering bernasib sama. Fakta ini menimbulkan kebingungan sehingga ia mengalami cognitive dissonance yang berujung pada kesimpulan bahwa carpe diem (menikmati hidup) adalah cara mengatasi kekusutan tersebut.

Berikutnya ialah tulisan berjudul "Hikmat Sebagai Implikasi Pendidikan Kristiani: Refleksi 1 Raja-Raja 3:1-15" yang ditulis oleh Harls Evan Rianto Siahaan. ${ }^{5}$ Tulisan tersebut mengaitkan hikmat Salomo dengan dunia pendidikan. Sikap Salomo yang taat dan tunduk ketika meminta hikmat dalam menanggapi tawaran Tuhan, direfleksikan dalam dunia pendidikan Kristen, dimana peserta didik diharapkan memiliki ketundukan yang serupa. Hikmat menjadi unsur penting dan mendasar dalam keberhasilan seseorang mengaktualisasi panggilan hidupnya, sehingga penting bagi dunia pendidikan Kristen untuk mengajar para peserta didik untuk memiliki sikap sebijak Salomo.

Tulisan lainnya datang dari Peniel C.D. Maiaweng yang berjudul "Understanding of Wisdom in the Book of Daniel." bahwa hikmat Daniel terkait dengan performa kerjanya, yang nampak pada cara bicaranya yang cerdas dan kejujuran dalam kerjanya. Hikmat Daniel juga terkait

${ }^{5}$ Harls Evan Rianto Siahaan, "Hikmat Sebagai Implikasi Pendidikan Kristiani: Refleksi 1 Raja-raja 3:1-15," DUNAMIS: Jurnal Penelitian Teologi dan Pendidikan Kristiani 1, no. 1 (1 Oktober 2016): 15, https://doi.org/10.30648/dun.v1i1.99.

${ }^{6}$ Peniel CD Maiaweng, "Understanding Of Wisdom In The Book Of Daniel," Jurnal Jaffray 14, no. 1 (2016): 93, http://dx.doi.org/10.25278/jj71.v14i1.192. 
dengan penyerahan, yang nampak pada penolakannya menyembah patung buatan Nebukadnezar dan penolakan terhadap dekrit Darius. Hikmat Daniel juga terkait dengan keterbebanannya bagi bangsanya, yang nampak pada doanya untuk Yerusalem, upayanya mewakili Israel di hadapan Tuhan, dan puasanya bagi masa depan. Hikmat dikaitkan dengan kinerja, spiritualitas, dann nasionalisme.

Karya-karya di atas mengulas perkembangan gagasan hikmat Israel berdasarkan Pengkhotbah (sastra hikmat), implikasi hikmat dalam dunia pendidikan berdasarkan 1Raja-raja (kitab sejarah), dan implementasi hikmat Daniel dalam pekerjaan, penyerahan dan keterbebannya bagi bangsa (kitab Nabinabi). Memang pada umumnya hikmat dalam Perjanjian Lama nampak dikaitkan dengan kemanusiaan, penciptaan, kota, pekerjaan, keluarga, pendidikan dan pemerintahan. ${ }^{7}$ Dalam penerlitian ini melihat kaitan hikmat dengan aspek yang lain, yakni misi bagi bangsa-bangsa. Kata חָכִמה (hokmâ) muncul di ayat 6 dan di

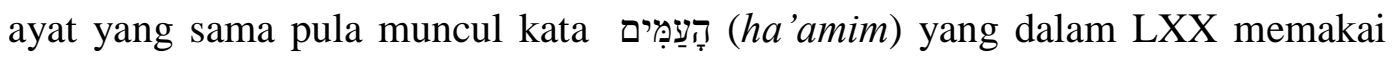
$\tau \tilde{\omega} v \dot{\varepsilon} \theta v \tilde{\omega} v$ (ton etnon). Penyelidikan terhadap U1. 4: 5-8 menunjukkan bahwa hikmat ada kaitannya dengan tugas Israel sebagai Kerajaan Imam agar menjadi saksi TUHAN bagi bangsa-bangsa lain.

Jadi bisa dilihat fakta bahwa: pertama, adanya kesan bahwa hikmat hanya disinggung dalam sastra hikmat dan beberapa mazmur; kedua adanya kaitan hikmat dan misi Israel. Karena alasan inilah artikel ini disusun dengan tujuan untuk membahas kaitan antara hikmat dalam misi Israel berdasarkan Ul. 4: 5-8, sehingga pembaca dicerahkan bahwa hikmat juga ada di luar sasrta hikmat dan berkontribusi dalam kegiatan misi. Kebaruan artikel hikmat ini nampak pada sub-

7 Bartholomew dan O'Dowd, Old Testament Wisdom Literature: A Theological Introduction, 1. 
aspek yang dibahas yakni misi dan pada referensi yang diambil yakni Kitab Ulangan.

\section{METODE}

Jenis penelitian di dalam artikel ini adalah penelitian kualitatif. Metode yang dipakai adalah studi literatur dan eksegesis teks Ul. 4: 5-8. Teori tentang hikmat dan misi diperoleh dari literatur yang relevan. Teks diteliti dengan analisis terjemahan, analisis struktur dan analisis konteks. Analisis terjemahan akan menggunakan BHS (Biblia Hebraica Stuttgartensia) sebagai teks Ibrani yang dirujuk. $^{8}$ Di dalamnya melibatkan analisis semantik dan gramatikal. Analisis struktur didapat melalui garis besar eksposisi baik dalam lingkup kitab, pasal dan teks yang dibahas dengan tujuan memahami alur pikir penulis kitab. Garis besar kitab dan pasal dapat diperoleh dari buku-buku tafsiran yang relevan, sedangkan struktur teks dapat dibuat dengan memperhatikan konjungsi, jenis kata, atau repetisi. Analisis konteks terkait dengan latar belakang teks dan posisi teks dalam keseluruhan kitab. Hal ini diperlukan agar penafsiran tidak keluar dari maksud asli penulis. Selanjutnya, pembahasan hasil penelitian akan disajikan secara deskriptif.

\section{HASIL}

Karya ilmiah ini berupaya menyumbangkan gagasan mengenai hikmat dalam literatur Perjanjian Lama di luar sastra hikmat. Penelitian ini juga menemukan bahwa hikmat berkontribusi dalam misi bagi segala bangsa. Dalam Perjanjian Lama, hikmat dikaitkan dengan kuasa ilahi dan kualitas manusia.

${ }^{8}$ Teks BHS adalah sebuah salinan persis dari teks masoret seperti yang dicatat dalam Kodeks Leningrad. BHS secara lapang dianggap (oleh orang Kristen maupun Yahudi) sebagai edisi yang akurat dari Kitab Suci Ibrani. 
Kualitas yang dimaksud meliputi intelektualitas, spiritualitas, ketrampilan praktis dan etika moral. Mutu hidup semacam ini sangat diperlukan bangsa Israel, terkhusus dalam tugas misinya. Tepat ketika Israel dipilih sebagai imamat rajani (Kel. 19: 4-6), Israel ditahbiskan sebagai imam bagi segala bangsa yang bertugas memperkenalkan TUHAN kepada mereka dan membawa mereka kepada pendamaian dengan TUHAN. Pola misi Israel adalah sentripetal dan sentrifugal. Artinya, Israel harus menunjukkan kualitas pribadi yang mengesankan orangorang tetapi juga harus pergi memberitakan TUHAN secara aktif. Semua ini ditemukan dalam Ulangan 4: 5-8, dimana Musa memperingatkan Israel untuk memelihara dan melakukan Taurat TUHAN sebab ketaatan inilah yang membuktikan hikmat mereka. Hikmat ini berimplikasi bagi tugas misional Israel. Setidaknya ada 3 implikasi hikmat Israel dalam misinya. Pertama, adanya unsur visibilitas dalam misi, dimana kehidupan Israel yang berhikmat dan kudus disaksikan oleh banyak pasang mata di sekeliling mereka sehingga tertarik untuk mempelajari hukum mereka. Kedua, adanya unsur pemberitaan dalam misi, di mana bangsa-bangsa yang terpukau itu dapat mendengar ketetapan TUHAN dan mengenal siapa Dia melalui pemberitaan aktif oleh bangsa Israel. Ketiga, adanya hasil yang dicapai, dimana bangsa-bangsa mengakui keistimewaan Israel dan akhirnya memuliakan TUHAN Allah Israel.

\section{PEMBAHASAN}

Bagian ini berisi penafsiran Ulangan 4: 5-8 mengenai hikmat dalam misi Israel. Namun sebelum sampai pada analisis teks, terlebih dahulu dipaparkan mengenai makna hikmat dalam Perjanjian Lama dan misi Israel sebagai Kerajaan 
Imam, sebagai dasar berpikir dalam menafsirkan Ulangan 4: 5-8. Poin penjelasan dari teks tersebut diperoleh berdasarkan garis besar eksegesis.

\section{Makna Hikmat dalam Perjanjian Lama}

Pertama-tama terlebih dulu akan dijelaskan secara singkat makna kata 'hikmat' dalam Perjanjian Lama. Bisa dikatakan bahwa hikmat merupakan sebuah konsep sentral di dalam Alkitab Perjanjian Lama maupun literatur Yahudi Awal. ${ }^{9}$ Kata 'hikmat' berasal dari kata Ibrani חָכִמה (hokmâ) dan bersinonim dengan kata pengetahuan, pengertian dan kebijaksanaan yang mengekspresikan berbagai ide yang terkait dengan ketertiban, keadilan, kebijaksanaan, dan jenis perilaku yang bermoral dan terampil. ${ }^{10}$ Lalu dalam pemakaiannya di Perjanjian Lama, hikmat terkait hal ilahi (Ams. 3: 19) dan insani (Dan. 1: 17), secara khusus kelebihan manusia dalam hal pengetahuan alam (1Raj. 4: 33), urusan kerajaan (Yes .19: 11), menggubah syair puitis (1Raj. 4: 32), meramalkan masa depan, menafsirkan mimpi, dan melakukan sihir (Kel. 7: 11; Dan. 5: 11). ${ }^{11}$ Lebih khusus lagi, hikmat terkait dengan kualitas etika yang berakar pada takut akan Tuhan dan teraplikasi dalam beragam bentuk relasi dan situasi. ${ }^{12}$

Dengan demikian, dapat dipahami bahwa חָכְמה (hokmâ) memiliki beragam pemakaian dalam Perjanjian Lama meliputi kuasa ilahi, kualitas intelektual, ketrampilan fisik, ketrampilan supranatural, dan kualitas etika dalam bermacam hubungan dan keadaan. Makna חָכְמה (hokmâ) menyesuaikan konteks dimana kata ini disebut, sehingga tidak ada makna tunggal di dalam Perjanjian Lama.

${ }^{9}$ Marko Marttila dan Mika S Pajunen, "Wisdom, Israel and Other Nations: Perspectives from the Hebrew Bible, Deuterocanonical Literature, and the Dead Sea Scrolls," Journal of Ancient Judaism 4, no. 1 (2013): 2, https://doi.org/10.30965/21967954-00401002.

10 Bartholomew dan O'Dowd, Old Testament Wisdom Literature: A Theological Introduction, 5.

11 DM Welton, "The old testament wisdom (Chokma)," The Biblical World 10, no. 3 (1897): 183, https://www.journals.uchicago.edu/doi/pdfplus/10.1086/472129.

12 Welton, 184. 


\section{Misi Israel sebagai Kerajaan Imam}

Ratusan tahun sebelum Israel lahir sebagai sebuah bangsa, leluhur mereka yakni Abraham telah menerima firman dari TUHAN yang memiliki nuansa misi dalam Kejadian 12: 1-3 dalam konteks janji berkat dalam kisah panggilan Abraham. Dalam nats tersebut, khususnya ayat 3, disebutkan bahwa oleh Abraham semua kaum di muka bumi akan mendapat berkat. Piper menyebut nats ini sebagai 'dasar visi misioner' bagi segala suku-bangsa sebab frase 'semua kaum' (kol-mishpahot) diterjemahkan dalam LXX dengan pasai hai phulai yang berarti 'setiap suku.' 13

Ketika keturunan Abraham telah menjadi sebuah bangsa yang besar bernama Israel di negeri perbudakan, TUHAN menginisiasi pembebasan mereka kemudian mengadakan kovenan dalam Keluaran 19: 4-6 yang dikenal sebagai Perjanjian Sinai. Di dalamnya, TUHAN menyebut Israel sebagai harta kesayangan, kerajaan imam dan bangsa yang kudus. Sebutan yang kedua, 'kerajaan imam', menjadi sorotan. Kaiser menyatakan bahwa gelar 'kerajaan imam' memperjelas peran misioner Israel dimana seluruh bangsa harus berfungsi sebagai perantara antara TUHAN dengan bangsa-bangsa. ${ }^{14}$ Wright mengemukakan bahwa sebagai kerajaan imam, Israel memiliki dua tugas utama yakni membawa pengetahuan tentang TUHAN kepada bangsa-bangsa dan membawa bangsa-bangsa ke dalam pendamaian dengan TUHAN, sama persis dengan dwi-tugas imam Perjanjian Lama, yakni mengajar Taurat yang memberi pengenalan akan TUHAN kepada umat (Im. 10: 11; Ul. 33: 10; Yer. 18: 18; Mal.

13 John Piper, Jadikan Sekalian Bangsa Bersukacita: Supremasi Allah dalam Misi, ed. oleh Doreen Widjana (Bandung: Lembaga Literatur Baptis, 2003), 290.

14 Walter C. J. Kaiser, Mission in the Old Testament: Israel as a Light to the Nations (Grand Rapids, Michigan: Baker Book, 2000), 13. 
2: 6) dan mempersembahkan korban sehingga umat bisa layak datang kepada TUHAN (Im. 1-7). ${ }^{15}$ Pemilihan Israel sebagai umat TUHAN sepaket dengan tugas misi-Nya, bahwa melalui keberadaan Israel di muka bumi diharapkan dapat memperkenalkan Allah yang benar kepada bangsa-bangsa sehingga mereka dapat dijangkau untuk datang bertekuk lutut menyembah TUHAN. Bangsa-bangsa yang bertobat ini dikenal dengan istilah 'proselit'.

Namun rupanya gelar 'kerajaan imam' tidak berdiri sendiri. Gelar ini terkait dengan gelar berikutnya, yakni 'bangsa yang kudus'. Tugas keimaman mereka tidak bisa dipisahkan dari praktik hidup yang kudus di mata bangsabangsa lain. Seok Cho berpendapat bahwa kekudusan Israel memiliki dimensi misional karena melalui kekudusan mereka, Israel menghadirkan kekudusan TUHAN di dunia. ${ }^{16}$ Mereka harus berkomitmen untuk hidup kudus, karena hanya dengan cara ini mereka dapat hidup untuk kemuliaan Allah, menarik datang orang kepada-Nya, dan menjadi terang bagi bangsa-bangsa. ${ }^{17}$ Israel adalah sarana di tangan TUHAN guna menjalankan misi ilahi di bumi. Tugas yang teramat mulia ini ditunaikan dengan tindakan persuasif dan kekudusan hidup.

Diskusi berikutnya tentang misi Israel ialah perihal pola misinya. Berkembang teori bahwa misi dikerjakan secara sentripetal dan sentrifugal. Sentripetal atau 'dari luar ke pusat' dimaksudkan bahwa bangsa-bangsa datang ke Israel dan sentrifugal atau 'dari pusat ke luar' dimaksudkan untuk pergi kepada bangsa-bangsa. Suara yang terdengar selama ini ialah bahwa pola misi Israel di

15 Chris Wright, "The Old Testament and Christian Mission," Evangel 14, no. 2 (1996): 37, http://biblicalstudies.gospelstudies.org.uk/pdf/evangel/14-2_037.pdf.

16 Ban Seok Cho, "The Nature of the Church's Mission in Llght of the Biblical Origin of Social Holiness," The Asbury Journal 73, no. 2 (2018): 13, https://doi.org/10.7252/Journal.02.2018F.11.

17 Jiri Moskala, "The mission of God's people in the Old Testament," Journal of the Adventist Theological Society 19, no. 1 (2008): 40, https://digitalcommons.andrews.edu/old-testament-pubs/9. 
Perjanjian Lama adalah sentripetal. ${ }^{18}$ Menurut Dumitrescu, kesimpulan semacam ini tidak memadai karena mengabaikan beberapa kitab dan beberapa bagian tertentu dalam Perjanjian Lama (Kej. 12: 1, 4; 13: 14-17; Kel. 5: 1; Mzm. 67; kitab Daniel, kitab Yoel, kitab Amos dan kitab Yunus). ${ }^{19}$ Grisanti menegaskan bahwa pola misi di dalam Perjanjian Lama melalui Israel adalah keduanya, yakni secara sentripetal (bergerak di dalam) maupun sentrifugal (bergerak keluar). ${ }^{20}$ Pola misi sentrifugal bisa dilihat dalam Kitab Yesaya, dimana sang nabi mengajarkan bahwa Israel menjadi utusan bagi bangsa-bangsa lain. ${ }^{21}$ Selanjutnya Matacio menyebutkan Yesaya 66: 19-21, dimana mereka yang bertahan di antara umat-Nya akan diutus TUHAN memberitakan kabar kemuliaan-Nya di antara bangsa-bangsa. $^{22}$ Demikianlah sekilas gambaran mengenai misi Israel sebagai bangsa imamat rajani yang kudus, di mana tanggung jawab misi terpikul di pundak mereka.

\section{Muatan Hikmat dan Misi dalam Ulangan 4: 5-8}

Mayer menyebutkan bahwa Ulangan 4 terdiri dari 6 bagian (ay. 1-4; ay. 58; ay. 9-14; ay. 15-22; ay. 23-31; dan ay. 32-40) di mana setiap bagian berisi

\footnotetext{
18 Derek Brotherson, "Terang Untuk Bangsa-Bangsa," TE DEUM (Jurnal Teologi Dan $\begin{array}{llllll}\text { Pengembangan Pelayanan) 2, no. } & 1 & \text { (2012): }\end{array}$ http://ojs.sttsappi.ac.id/index.php/tedeum/article/view/118/98. Choi Yong Sung, "Kompetensi Kerjasama Misi Lintas Budaya Misionaris PCK Dengan Pemimpin Gereja Lokal Indonesia," JURNAL LUXNOS 5, no. 2 (2019): 111, https://doi.org/10.47304/jl.v5i2.20.Kedua artikel ini memiliki pendapat bahwa pola sentripetal adalah gambaran misi Perjanjian Lama dan pola sentrifugal adalah gambaran misi Perjanjian Baru.

${ }^{19}$ Cristian Dumitrescu, "Mission Theology in the Old Testament: A New Paradigm," Journal of $\begin{array}{lllllll}\text { Adventist } \quad \text { Mission } & \text { Studies } & \text { 4, } & \text { no. } & 1 & \text { (2008): } & 43 \text {, }\end{array}$ https://digitalcommons.andrews.edu/cgi/viewcontent.cgi?article=1099\&context=jams.

20 Michael A Grisanti, "Israel's Mission to the Nations in Isaiah 40-55: an Update," The Master's Seminary Journal 9, no. 1 (1998): 39, http://www.tms.edu/m/tmsj9c.pdf.

21 Grisanti, 45-46.

22 Doug Matacio, "Centripetal and 'Centrifugal' Mission: Solomon and Jesus," Journal of Adventist

$\begin{array}{llllll}\text { Mission Studies } & 4, & \text { no. } & 1 & \text { (2008): } & 32 \text {, }\end{array}$ https://digitalcommons.andrews.edu/cgi/viewcontent.cgi?referer=https://scholar.google.com/\&httpsredir=1\&ar ticle=1098\&context=jams.
} 
peringatan pembuka untuk mengindahkan Taurat dan referensi untuk sejarah. ${ }^{23}$ Ayat 5-8 merupakan bagian yang kedua dari pasal 4. Barret turut menambahkan, bahwa ayat 5-8 adalah sub-bagian dari introduksi pasal 4 yang menampilkan pengagungan Musa atas perintah-perintah TUHAN yang diajarkan kepada Israel. ${ }^{24}$ Serupa dengan Barret, Kruger juga berpendapat bahwa ay. 5-8 merupakan bagian dari pidato kedua Musa dalam 4: $1-40 .^{25}$

Menemukan muatan hikmat dalam Ulangan adalah sebuah keniscayaan. Teologi, bahasa dan metafora hikmat dapat ditemukan juga di dalam Ulangan. ${ }^{26}$ Musa, yang diyakini teolog konservatif sebagai penulis Kitab Ulangan, cukup akrab dengan hikmat sehingga bukan perkara mustahil jika Musa menyinggung hikmat di dalam Ulangan 4: 5-8. Dalam Mazmur 90: 12, Musa membahas 'hati yang bijaksana' dan dalam Kisah Para Rasul 7: 22 Musa dijelaskan mengalami pendidikan hikmat di Mesir. Barangkali pengalaman akademiknya tersebut berkontribusi sebagai ide dasar hikmatnya. Goldsworthy menyebut bahwa pendidikan dan hasil dari sekolah hikmat tersebut tidaklah sia-sia, tetapi justru mempersiapkan Musa. ${ }^{27}$

Apabila diamati dengan saksama, maka akan ditemukan struktur chiasme ${ }^{28}$ Ulangan 4: 5-8 menunjukkan ayat 5 sejajar dengan ayat 6-7, di mana masing-

${ }^{23}$ Andrew DH Mayes, "Deuteronomy 4 and the Literary Criticism of Deuteronomy," Journal of Biblical Literature 100, no. 1 (1981): 25, https://doi.org/10.2307/3265533.

${ }^{24}$ Rob Barrett, SDE Weeks, dan RWL Moberly, Deuteronomy 4 and the Coercion of Israel, vol. 20 (Durham: Department of Theology and Religion University of Durham, 2005), 6, http://www.coffeewithbarretts.com/writings/Deut4.pdf.

25 Thomas Kruger, "Law and Wisdom according to Deut. 4:5-8," dalam Wisdom and Torah: The Reception of 'Torah' in the Wisdom Literature of the Second Temple Period, ed. oleh Bernd U. Schippe dan D. Andrew Teeter (Leiden, Boston: Brill, 2013), 35.

${ }^{26}$ Bartholomew dan O'Dowd, Old Testament Wisdom Literature: A Theological Introduction, 5.

27 Graeme Goldsworthy, "Wisdom and its literature in biblical-theological context," Southern Baptist Journal of Theology 15, no. 3 (2011): 52, https://sbts-wordpressuploads.s3.amazonaws.com/equip/uploads/2012/02/pages-from-sbjt-v15-n3_goldsworthy.pdf.

${ }_{28}$ Chiasme dapat diartikan sebagai sebuah perangkat struktur umum lain yang di dalamnya susunan kata dari baris paralel ditempatkan dalam urutan terbalik dengan baris sebelumnya. William W. 
masing bagian mencantumkan frase 'ketetapan dan peraturan' serta 'TUHAN Allah'. Sedangkan yang menjadi pokok dalam unit gagasan ini adalah ayat 6 , yang menekankan hikmat di mata bangsa-bangsa.

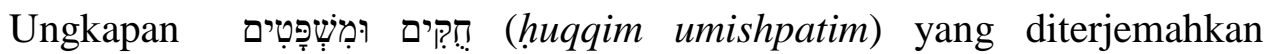

'ketetapan dan peraturan' menunjuk pada Taurat. ${ }^{29}$ Gaya bahasa hendiadis dipakai di sini, yakni gaya bahasa yang mengekspresikan satu ide melalui dua kata

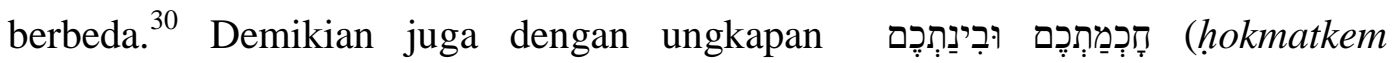
uvinatkem) yang diterjemahkan 'kebijaksanaanmu dan akal budimu' yang keduanya bermakna 'hikmat'.

\section{Implementasi Hikmat melalui Praktik Taurat}

Dalam konteks Kitab Ulangan, Musa sedang berada di dataran Moab untuk memimpin orang-orang dalam pembaruan perjanjian sebelum mereka melakukan perang penaklukan untuk tanah yang dijanjikan kepada para leluhur, sekaligus menyiapkan orang-orang untuk kematiannya. ${ }^{31}$ Perintah Musa untuk setia pada kovenan dan mematuhi Taurat TUHAN muncul di sepanjang kitab kelima dari Torah ini. Termasuk di dalamnya juga, tercantum fakta bahwa implementasi hikmat adalah melalui pelaksanaan Taurat.

Klein, Craig L. Blomberg, dan Robert I. Hubbard Jr., Introduction To Biblical Interpretation 2, ed. oleh Chilianha Jusuf (Malang: Literatur SAAT, 2017), 120. Berikut Struktur Chiasme dalam Ulangan 4: 5-8. Strukturnya dapat dilihat sebagai berikut:

A. Ingatlah, aku telah mengajarkan ketetapan dan peraturan kepadamu, seperti yang diperintahkan kepadaku oleh TUHAN, Allahku, supaya kamu melakukan yang demikian di dalam negeri, yang akan kamu masuki untuk mendudukinya. (Ay. 5)

B. Lakukanlah itu dengan setia, sebab itulah yang akan menjadi kebijaksanaanmu dan akal budimu di mata bangsa-bangsa yang pada waktu mendengar segala ketetapan ini akan berkata: Memang bangsa yang besar ini adalah umat yang bijaksana dan berakal budi (Ay. 6)

A. Sebab bangsa besar manakah yang mempunyai allah yang demikian dekat kepadanya seperti TUHAN, Allah kita, setiap kali kita memanggil kepada-Nya? Dan bangsa besar manakah yang mempunyai ketetapan dan peraturan demikian adil seperti seluruh hukum ini, yang kubentangkan kepadamu pada hari ini? (Ay. 7-8) ${ }^{29}$ Kruger, "Law and Wisdom according to Deut. 4:5-8," 38.

${ }^{30}$ Eugene E. Merrill, The New American Commentary: Deuteronomy, 4 ed. (Nashville, Tennesse: B\&H Publishing Group, 1994), 55.

31 Tremper Longman dan Raymond B. Dillard, An introduction to the Old Testament (Grand Rapids, Michigan: Zondervan, 2009), 102. 
Ayat 5 dibuka dengan perintah Musa "ingatlah." Kata yang dipakai adalah רָהָה ( $\left.r^{e} e\right)$, yakni kata dalam bentuk imperatif yang lebih cocok diartikan 'melihat', tetapi bukan sekedar 'melihat' melainkan 'melihat untuk memahami'. ${ }^{32}$ Makna ini nampaknya lebih sesuai, sebab di dalam klausa berikutnya mencantumkan frase

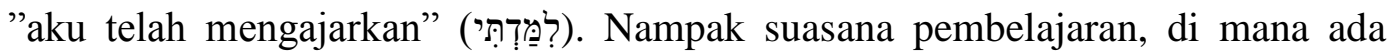
ajaran yang menuntut pemahaman, sebagaimana lazim dalam literatur hikmat.

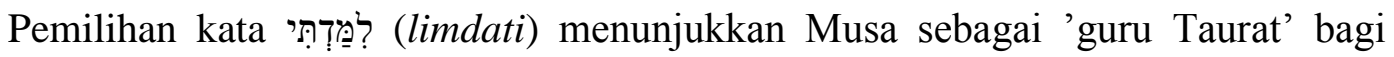
umat Israel. ${ }^{33}$ Namun Musa bukanlah guru sembarangan karena ia mengajarkan Taurat kepada Israel dengan otoritas ilahi sebagaimana disebut secara tegas dalam klausa "seperti yang telah diperintahkan kepadaku oleh TUHAN Allahku." Umat Israel tidak hanya diperintahkan untuk melihat dan memahami Taurat, tetapi untuk melakukannya sebagaimana terlihat pada kata עָ (asa) di ayat 5 dan 6.

Selanjutnya, teks LAI memberi keterangan "dengan setia" pada ayat 6 awal. Frase terjemahan tersebut agaknya kurang tepat, sebab teks asli memakai

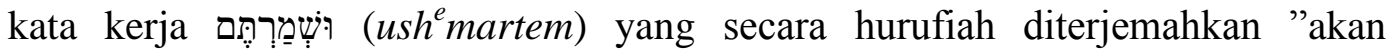

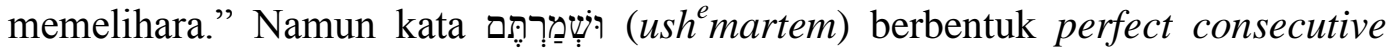
yang bisa bermakna perintah atau harapan. ${ }^{34}$ Oleh sebab itu terjemahan yang cocok adalah "kalian peliharalah" atau "kiranya kalian memelihara." Hal yang serupa berlaku untuk kata kedua di ayat 6, yakni וַעְשׁׁיתֶة (wa'asitem). Dengan demikian perintah di awal ayat 6 ialah "kalian peliharalah dan lakukanlah."

32 Francis Brown, S. Driver, dan C. Briggs, A Hebrew and English Lexicon of the Old Testamen (Oxford: Clarendon, 1907), 906. Kata רָ רָָ memiliki beberapa makna dalam pemakaiannya tergantung konteks yang mendukung.

${ }^{33}$ Kruger, "Law and Wisdom according to Deut. 4:5-8," 42-43.

${ }^{34}$ A. E. Cowley, Gesenius' Hebrew Grammar (New York: Oxford University Press, 1910), $335 .$. Secara umum, bentuk perfect consecutive digunakan untuk menjelaskann kegiatan di masa depan. 
Motif dari ketaatan terhadap Taurat ini ialah hubungan yang dekat dengan TUHAN. Ayat 7 menjelaskan bahwa TUHAN sedemikian dekat dengan umatNya. Secara konteks, kedekatan yang dimaksud menunjuk pada peristiwa teofani di gunung Sinai (Kel. 19) di mana TUHAN datang kepada umat-Nya dalam api, asap dan suara bergemuruh untuk menyatakan perjanjian dan hukum-Nya. ${ }^{35}$ Peristiwa dramatik ini sebaiknya jangan dimaknai sebaga sebuah teror dari TUHAN. Penekanan dari ayat 7 ini ialah 'hubungan yang dekat' antara Israel dengan TUHAN. ${ }^{36}$ Selain hubungan yang dekat, motif dari dari ketaatan akan Taurat adalah natur dari Taurat itu sendiri, yakni kebenaran. Di ayat 8, Lembaga Alkitab Indonesia (LAI) menyebut kata 'adil' terkait Taurat. Teks asli memakai kata צִ צִדִיק (tsadiq) yang berarti 'kebenaran'. Kebenaran dalam konteks ini mengacu pada tindakan etis yang nyata, sebagai wujud kepatuhan kepada norma yang berlaku. $^{37}$

Ayat 6 bagian awal menjelaskan bahwa tindakan aktif memelihara dan melakukan Taurat 'adalah' hikmat Israel. Pemilihan kata 'adalah' lebih cocok daripada 'akan menjadi'. Terjemahan New American Standard (NAS) pun memakai is, bukan will be. Klausa "sebab itulah yang akan menjadi menjadi

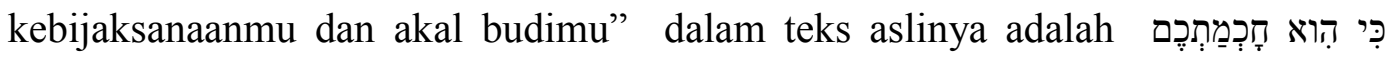

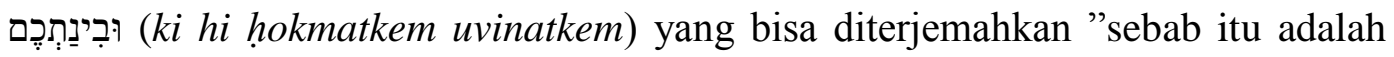
kebijaksanaanmu dan akal budimu.” Menurut Merill, Musa sedang menunjukkan

35 Merrill, The New American Commentary: Deuteronomy, 56. Kruger, "Law and Wisdom according to Deut. 4:5-8," 47.

${ }^{36}$ Marko Marttila dan Mika S. Pajunen, "Wisdom, Israel and Other Nations," Journal of Ancient Judaism 3 (2012): 6.

37 Daniel I. Block, The NIV Application Commentary: Deuteronomy (Grand Rapids, Michigan: Zondervan, 2017), 119.. 
bahwa praktik Taurat mendefinisikan hikmat itu sendiri. ${ }^{38}$ Martilla dan Pujanen pun melihat bahwa di bagian ini hukum dan hikmat terikat erat, dimana hukum adalah prasyarat yang diperlukan untuk mencapai hikmat."39

Beberapa bagian lain dalam Perjanjian Lama rupanya menyuguhkan gagasan serupa. Sebut saja Amsal 28: 7 yang berbunyi: "Orang yang memelihara hukum (taurat) adalah anak yang berpengertian (hikmat)" serta Mazmur 19 dan 119 yang mengajarkan bahwa hikmat ditentukan oleh Taurat, bahwa Taurat adalah perantara hikmat. ${ }^{40}$ Beberapa ayat dari kedua mazmur tersebut kiranya semakin mempertegas gagasan yang dibicarakan. Mazmur 19: 8b dan 119: 104a menunjukkan bahwa hikmat terimplementasi dalam praktik Taurat. Hikmat bukan sekadar semboyan yang lantang diteriakkan, namun lebih dari itu, terejawantah dalam kepatuhan melakukan Taurat TUHAN.

\section{Implikasi Hikmat dalam Misi Umat}

Hikmat Israel menyulut respon dari bangsa-bangsa lain. Inilah sasaran dari misi umat TUHAN. Bagian ini akan membahas dampak hikmat dalam tugas kesaksian bagi bangsa-bangsa melalui pengamatan beberapa frasa dan klausa di ayat 6. Tiga kata kunci yang dibahas ialah 'di mata', 'mendengar' dan 'berkata' yang terkait pengalaman indrawi bangsa-bangsa dalam merespon hikmat Israel.

\section{Bangsa-bangsa Melihat}

Implikasi pertama dari hikmat Israel ialah bahwa bangsa-bangsa dapat melihat kesaksian hidup orang-orang Israel. Ayat 6 menjelaskan bahwa jika mereka melaksanakan Taurat, maka mereka disebut berhikmat "di mata bangsa-

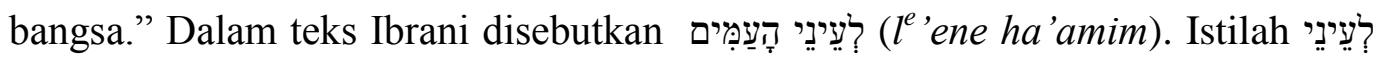

38 Merrill, The New American Commentary: Deuteronomy, 56.

${ }^{39}$ Marttila dan Pajunen, "Wisdom, Israel and Other Nations," 6.

40 Kruger, "Law and Wisdom according to Deut. 4:5-8," 45-46. 
( $l^{e}$ ene) berasal dari kata (ayin) yang tidak sekedar diartikan sebagai organ penglihatan, tetapi juga bisa mengekspresikan sikap dan respon. ${ }^{41}$ Penekanan bagian ini ialah ketaatan dan hikmat Israel memiliki aspek visual yang bisa dilihat orang lain.

Telah diulas sebelumnya bahwa hikmat bisa dimaknai sebagai kualitas etika dan bahwa 'kebenaran' dalam Taurat menunjuk kepada tindakan etis seseorang. Artinya dengan menaati Taurat sebagai bukti hikmatnya, Israel seharusnya memperlihatkan kekudusan etika-moral dalam kehidupan sosial bermasyarakat. Seok Cho mengatakan bahwa kekudusan moral dan Taurat memiliki kaitan, sehingga Israel harus menampilkan pola hidup yang kudus di mata bangsa-bangsa lain dan dengan demikian merefleksikan kekudusan TUHAN kepada mereka. ${ }^{42}$ Nampak bahwa kekudusan ini dalam rangka memperkenalkan TUHAN di antara bangsa-bangsa. Wright menambahkan, bahwa Israel harus dikenali dan terlihat berbeda secara substantif, sebagai orang-orang yang secara unik menjadi umat TUHAN dan karena itu Israel mewakili karakter dan jalan-Nya kepada bangsa-bangsa yang belum mengenal-Nya sebagai Tuhan. ${ }^{43}$ Rupanya kekudusan hidup dengan standar Taurat mampu membuat Israel menjadi terlihat berbeda di antara bangsa-bangsa lain di sekeliling mereka yang praktik sosioreliginya cenderung bercirikan amoralitas seksual, kekerasan, sihir, ramalan dan

41 "עִ", TWOT 1612 dalam R. Laird Harris, Theological Wordbook of the Old Testament, 1 \& 2 ed. (Chicago: Moody Press, 1980).

${ }^{42}$ Cho, "The Nature of the Church's Mission in Llght of the Biblical Origin of Social Holiness," 13.

43 Wright, "The Old Testament and Christian Mission," 38. 
penyembahan berhala. ${ }^{44}$ Konsekuensi logisnya, bangsa-bangsa akan terheran dan terpukau ketika melihat perbedaan semacam ini.

Kekudusan Israel disebut memiliki aspek misiologi dan hal ini terjadi dalam rangka penggenapan janji TUHAN untuk memberkati segala bangsa sebagaimana tertulis dalam Kejadian 12: 3 dan 18: $18-19 .{ }^{45}$ Dalam janji ini, pilihan, etika dan misi adalah tiga aspek yang berkaitan tanpa terpisahkan. ${ }^{46}$ Israel tidak bisa mengabaikan identitasnya sebagai bangsa pilihan yang kudus dan imamat rajani, dengan mengemban misi sebagai berkat bagi bangsa-bangsa. Umat TUHAN dituntut menghidupi jati dirinya melalui kehidupan yang suci secara etika, moral dan sosial. Israel ada di muka bumi karena misi, dan sasaran TUHAN ialah menjangkau bangsa-bangsa. ${ }^{47}$ Jadi kaitan hikmat dan misi terletak pada kesaksian hidup umat TUHAN yang membuka jalan bagi orang lain untuk tertarik mengenal-Nya.

\section{Bangsa-bangsa Mendengar}

Implikasi kedua dari hikmat Israel ialah bahwa bangsa-bangsa dapat mendengar ketetapan TUHAN. Ayat 6 memiliki klausa yang berbunyi "pada

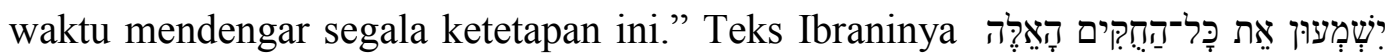
(yishme'un et kol-hahuqqim ha'elle) yang cocok diterjemahkan ”akan mendengar segala ketetapan-ketetapan ini.” Yang dimaksud tentunya adalah Taurat TUHAN. Melalui Taurat TUHAN, seseorang dapat mengenal Dia dan kehendak-Nya. Pertanyaan yang muncul ialah: bagaimana bangsa-bangsa bisa mendengar

44 Jey J. Kanagaraj, Mission and Missions (Pune: Work Center Offset Printers, 1998), 43. Misalnya saja dalam ritual penyembahan Molokh (dewa api) dengan mengorbankan bayi manusia yang dibakar hidup-hidup atau penyembahan Asytoret (dewi kesuburan) dengan pelacuran bakti

45 Christopher J.H. Wright, "Truth with a Mission: Reading All Scripture Missiologically," The Southern Baptist Journal of Theology 15, no. 2 (2011): 12.

46 Wright, 12.

47 Dumitrescu, "Mission Theology in the Old Testament: A New Paradigm," 50. 
ketetapan TUHAN dan mengenal-Nya? Jawabannya tidak mudah, sebab Ulangan tidak memberi banyak petunjuk tentang hal ini. Petunjuk yang dianggap paling jelas adalah dalam Ulangan 31: 12 di mana orang asing yang sudah diam bersama Israel yang bisa mendengar Taurat TUHAN dan belajar takut akan Dia. Menurut Block, bangsa-bangsa lain melihat hikmat Israel lalu tertarik dan datang untuk mempelajari tata cara yang mengatur kehidupan mereka. ${ }^{48}$

Jika bergerak sedikit lebih luas ke kitab-kitab lain, maka akan didapatkan dukungan-dukungan yang memadai. Kruger menyatakan bahwa beberapa nats seperti Yesaya 2: 3; 42: 1; 51: 4 dan Mikha 4: 2 secara gamblang menyebut tentang pemberitaan Taurat kepada bangsa-bangsa. ${ }^{49}$ Keempat ayat tersebut adalah ayat propetik yang di antaranya digenapi secara eskatologis. Riecker menyebut di dalam Keluaran, Imamat dan Bilangan setidaknya ada dua puluh ayat mengenai pengetahuan akan TUHAN yang terkait Israel maupun bangsa-bangsa lain. ${ }^{50}$ Riecker melihat ketiga kitab tersebut secara kanonis sebagai kesatuan dalam Torah (Kel. 6: 7; 7: 5, 17; 8: 6, 18; 9: 14, 29; 10: 2; 11: 7; 14: 4, 18; 16: 6, 12; 18: 11; 29: 46; 31: 13; Im. 23: 43; Bil. 14: 34; 16: 28, 30). Kemudian Olson mengungkap ada sekitar 175 referensi dalam Kitab Mazmur tentang bangsabangsa dan di antaranya terkait ketetapan dan pengenalan akan TUHAN kepada mereka. ${ }^{51}$ Bahkan beberapa pasal seperti Mazmur 2, 33, 66, 67, 72, 96, 98, 100,

\footnotetext{
48 Block, The NIV Application Commentary: Deuteronomy, 118.

49 Kruger, "Law and Wisdom according to Deut. 4:5-8," 44.

50 Siegbert Riecker, "Missions In The Hebrew Bible Revisited: Four Theological Trails Instead Of One Confining Concept," Missiology: An International Review, 2016, 5. 2003), 23.

${ }^{51}$ C. G. Olson, What in the World is God Doing? (Cedar Knolls, NJ: Global Gospel Publishers,
} 
117, dan 145 disebut sebagai "mission psalm" yang di dalamnya para pemazmur memproklamasikan TUHAN. ${ }^{52}$

Konteks budaya dan politik Timur Dekat Kuno memberi dukungan bahwa pemberitaan Taurat dilakukan secara aktif. Deuel menyebutkan, di era Daud bahkan sebelumnya, lazim bagi suatu kerajaan untuk mengirim imam guna mengajarkan hukum-hukum agama kepada seluruh warga di segala penjuru negeri, bahkan kepada orang asing dalam wilayah dalam rangka indoktrinasi dan akulturasi. $^{53}$ Daud mempraktikkan hal ini setelah memperluas wilayah kerajaannya. Dalam 1Tawarikh 26: 30 dijelaskan bahwa Daud mengirim seorang keturunan Lewi bernama Hasabya ke sebelah barat sungai Yordan untuk menangani urusan terkait TUHAN. ${ }^{54}$ Dapat dikatakan bahwa sebagai kekuatan regional, Israel mengirim misi Taurat ke orang-orang yang kehilangan haknya di area kekuasaan Israel, termasuk orang-orang asing dari bangsa lain. ${ }^{55}$ Dalam 2 Tawarikh 2: 17 tercatat ada 153.600 orang asing di negeri Israel. Tak bisa disangkal, bahwa Israel juga melakukan misi pemberitaan Taurat dan pengenalan akan TUHAN secara aktif dan masif.

Mengingat Israel adalah bangsa imam yang dipilih TUHAN, maka salah satu tugasnya adalah membawa bangsa-bangsa lain mendekat kepada-Nya dengan memberitakan wahyu TUHAN. ${ }^{56}$ Imam yang mengajarkan Taurat disebut juga

\footnotetext{
52 Riecker, "Missions In The Hebrew Bible Revisited: Four Theological Trails Instead Of One Confining Concept," 9.

${ }^{53}$ David Deuel, "Early Torah Missions," Journal of the Evangelical Theological Society 60, no. 2 (2017): 302, https://www.proquest.com/docview/1964553491?pq-origsite=gscholar\&fromopenview=true.

54 Deuel, 311.

55 Deuel, 316.

${ }^{56} \mathrm{R}$ Omwenga, "Mission to people of other faiths in the Old Testament and Eldoret, Kenya: Some reflections for engaging Muslims within their context," Acta theologica 35, no. 1 (2015): 138, https://hdl.handle.net/10520/EJC172466.
} 
sebagai 'utusan' atau 'messenger' (mal'ak). ${ }^{57}$ Dengan demikian sudah sewajarnya jika Israel sebagai bangsa imamat 'diutus' keluar kepada bangsa-bangsa lain. Beberapa kisah naratif dalam Perjanjian Lama menunjukkan bahwa tugas ini dilaksanakan, antara lain kisah Elisa dengan Naaman yang terkena kusta, kisah Elisa dengan Raja Ben-Hadad, kisah Daniel, Sadrakh, Mesakh, Abednego di kerajaan Babel, dan tentunya kisah Yunus diutus ke Niniwe. Meskipun mereka adalah nabi dan pegawai pemerintahan, mereka menjalankan tugas misinya sebagai warga bangsa yang imamat rajani. Bukti-bukti yang terkumpul telah menunjukkan bahwa bangsa asing bisa mendengar ketetapan TUHAN dan mengenal-Nya melalui dua pola, yaitu secara sentripetal dan sentrifugal.

\section{Bangsa-bangsa Mengakui}

Implikasi ketiga dari hikmat Israel ialah bahwa bangsa-bangsa akhirnya mengakui hikmat umat Israel. Pada bagian akhir ayat 6 dikatakan: "Akan berkata: Memang bangsa yang besar ini adalah umat yang bijaksana dan berakal budi.”

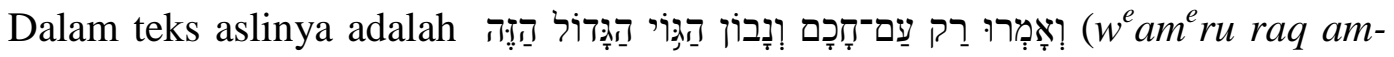
hakom w' navon haggoy haggadol hazze). Dalam bagian ini tidak ada perbedaan berarti antara terjemahan LAI dengan teks asli. Namun yang menarik ialah nampak ada urutan di ayat 6. Bangsa-bangsa melihat, lalu mendengar dan kemudian mereka berkata $\left(a m^{e} r u\right)$. Dalam bagian ini lah tujuan nasihat Musa tercapai. Menurut Krugger teks ini berisi kerinduan Musa bahwa bangsa-bangsa akan mengakui Israel melalui ketaatan dan hikmat mereka. ${ }^{58}$ Kalimat tersebut bisa dipahami sebagai ekspresi kekaguman bangsa-bangsa, teristimewa melalui kata רִ 
(raq) yang dalam bahasa sehari-hari bisa diterjemahkan "wow!",59 Bisa juga dilihat bahwa teks ini menggenapi janji TUHAN bagi Israel sebagai berkat bagi bangsa-bangsa di seluruh bumi. ${ }^{60}$ Kesaksian hidup dan pemberitaan Taurat membawa pada pengakuan dan kekaguman yang jujur dari bangsa-bangsa lain.

Pengakuan bangsa-bangsa ini tidak berarti bahwa Israel adalah sasaran segala pujian. Muaranya tetap saja kemuliaan bagi TUHAN. Ketika Israel diangkat menjadi umat-Nya, artinya Israel siap untuk merepresentasikan TUHAN dan karakter-Nya ke seluruh dunia. ${ }^{61}$ Beberapa kisah tokoh memperjelas fakta tersebut, bahwa ketika seorang Israel dilihat berhikmat, pujian dipanjatkan kepada TUHAN. Hal tersebut terlihat dalam kisah kerjasama Salomo dengan Hiram raja Tirus terkait penyediaan material pembangunan Bait Suci (Lih. 1Raj. 5: 1-18). Ayat 7 menuliskan respon Hiram, yakni: "Terpujilah TUHAN pada hari ini karena Ia telah memberikan kepada Daud anak yang bijaksana.” Selanjutnya kisah kedatangan ratu negeri Syeba kepada Salomo (2Raj. 10: 1-13). Ayat 1 menyebutkan bahwa sang ratu 'mendengar kabar tentang Salomo berhubung nama TUHAN'. Ayat 4-5 menjelaskan sang ratu tercengang melihat hikmat Salomo, etika pegawainya dan ibadah Israel. Lalu dalam ayat 9 sang ratu mengatakan: "Terpujilah TUHAN, Allahmu." Dua kisah naratif ini menunjukkan bahwa bangsa lain juga mendengar tentang Allah Israel, selain tentang hikmat bangsa Israel. ${ }^{62}$ Terkait dengan itu ada kisah Daniel yang menafsirkan mimpi Nebukadnezar dalam Daniel 2. Kebijaksanaan Daniel dalam menafsir mimpi sang

${ }^{59}$ Block, The NIV Application Commentary: Deuteronomy, 118.

60 Merrill, The New American Commentary: Deuteronomy, 56.

61 R. Bryan Widbin, "Salvation for People Outside Israel's Covenant?," Through No Fault of Their Own? The Fate of Those Who Have Never Heard, ed. oleh W. V. Crockett and J. G. Sigountos (Grand Rapids: Baker, 1991), 74.

62 Moskala, "The mission of God's people in the Old Testament," 51. 
raja mampu membuatnya bersujud dan menyatakan: "Sesungguhnyalah, Allahmu itu Allah yang mengatasi segala allah dan yang berkuasa atas segala raja.” Glover menganggap Daniel sebagai ‘missionaris' yang bersaksi kepada empat raja di era berbeda tentang superioritas TUHAN dan kerajaan-Nya yang universal. ${ }^{63}$ Lihatlah bahwa hikmat orang Israel dapat memukau seseorang sampai memuliakan TUHAN.

Bagian akhir dari ayat 6 ini menjelaskan tujuan yang berhasil dicapai dari misi Israel, yakni bahwa bangsa-bangsa mengakui hikmat Israel kemudian mengenal dan mengagungkan Allah Israel. Pengakuan ini diharapkan sebagai kesaksian verbal oleh bangsa-bangsa kepada orang di dalam wilayah mereka maupun di sekitar mereka. Dengan demikian, ada kesaksian yang berkesinambungan.

\section{KESIMPULAN}

Dari serangkaian pembahasan yang telah dipaparkan, maka dapat dipahami bahwa hikmat Israel memiliki sumbangsih dalam misi Israel sebagai bangsa pilihan dan imamat yang rajani. Misi Israel bersifat pasif maupun aktif, melalui being maupun doing, dengan pola sentripetal maupun sentrifugal. Hasil dari tugas tersebut, bangsa-bangsa mampu melihat hikmat, kekudusan, mendengar Taurat dan Allah dan akhirnya terberkati hingga mengakui keunikan Israel. Dengan demikian tujuan misiologis TUHAN memilih Israel pun terealisasi dengan baik. Relevansi temuan ini bagi orang percaya masa kini ialah: pertama, orang Kristen yang dipilih menjadi umat Allah, juga dipilih sebagai mitra misi-

63 Robert H. Glover, The Bible Basis of Mission (Los Angeles: Bible of Los Angeles, 1946), 21. 
Nya; kedua, orang Kristen perlu menunjukkan kehidupan yang berhikmat melalui ketaatan pada kehendak Allah; ketiga, misi dilakukan secara dengan menampilkan kehidupan yang saleh di mata masyarakat dan dengan pemberitaan kabar baik secara verbal. Penelitian ini kiranya berkontribusi bagi studi teologi biblika Perjanjian Lama dan missiologi, di mana hikmat tidak hanya ditemukan dalam sastra hikmat maupun mazmur, tetapi juga terdapat dalam Torah dan berkontribusi bagi kegiatan misi.

\section{DAFTAR PUSTAKA}

Baltes, Paul B, dan Jacqui Smith. "The fascination of wisdom: Its nature, ontogeny, and function." Perspectives on psychological science 3, no. 1 (2008): 56-64. https://doi.org/10.1111\%2Fj.1745-6916.2008.00062.x.

Barrett, Rob, SDE Weeks, dan RWL Moberly. Deuteronomy 4 and the Coercion of Israel. Vol. 20. Durham: Department of Theology and Religion University of Durham, 2005. http://www.coffeewithbarretts.com/writings/Deut4.pdf.

Bartholomew, Craig G., dan Ryan P. O’Dowd. Old Testament Wisdom Literature: A Theological Introduction. Downers Grove, IL: InterVarsity Press, 2011.

Block, Daniel I. The NIV Application Commentary: Deuteronomy. Grand Rapids, Michigan: Zondervan, 2017.

Brotherson, Derek. "Terang Untuk Bangsa-Bangsa." TE DEUM (Jurnal Teologi Dan Pengembangan Pelayanan) 2, no. 1 (2012): 215-33. http://ojs.sttsappi.ac.id/index.php/tedeum/article/view/118/98.

Brown, Francis, S. Driver, dan C. Briggs. A Hebrew and English Lexicon of the Old Testamen. Oxford: Clarendon, 1907.

Cho, Ban Seok. "The Nature of the Church's Mission in LIght of the Biblical Origin of Social Holiness." The Asbury Journal 73, no. 2 (2018): 13. https://doi.org/10.7252/Journal.02.2018F.11.

Cowley, A. E. Gesenius' Hebrew Grammar. New York: Oxford University Press, 1910.

Deuel, David. "Early Torah Missions." Journal of the Evangelical Theological $\begin{array}{llll}\text { Society } & 60, & \text { no. } & 2017):\end{array}$ 
https://www.proquest.com/docview/1964553491?pqorigsite $=$ gscholar $\&$ fromopenview $=$ true.

Dumitrescu, Cristian. "Mission Theology in the Old Testament: A New Paradigm." Journal of Adventist Mission Studies 4, no. 1 (2008): 43-62. https://digitalcommons.andrews.edu/cgi/viewcontent.cgi?article=1099\&co ntext=jams.

Glover, Robert H. The Bible Basis of Mission. Los Angeles: Bible of Los Angeles, 1946.

Goldsworthy, Graeme. "Wisdom and its literature in biblical-theological context." Southern Baptist Journal of Theology 15, no. 3 (2011): 42-55. https://sbtswordpress-uploads.s3.amazonaws.com/equip/uploads/2012/02/pagesfrom-sbjt-v15-n3_goldsworthy.pdf.

Grisanti, Michael A. "Israel's Mission to the Nations in Isaiah 40-55: an Update." The Master's Seminary Journal 9, no. 1 (1998): 39-61. http://www.tms.edu/m/tmsj9c.pdf.

Gunkel, Hermann, dan Joachim Begrich. Introduction to the Psalms: The Genres of the Religious Lyric of Israel. Macon, Georgia: Mercer University Press, 1998.

Harris, R. Laird. Theological Wordbook of the Old Testament. 1 \& 2 ed. Chicago: Moody Press, 1980.

Kaiser, Walter C. J. Mission in the Old Testament: Israel as a Light to the Nations. Grand Rapids, Michigan: Baker Book, 2000.

Kanagaraj, Jey J. Mission and Missions. Pune: Work Center Offset Printers, 1998.

Klein, William W., Craig L. Blomberg, dan Robert I. Hubbard Jr. Introduction To Biblical Interpretation 2. Disunting oleh Chilianha Jusuf. Malang: Literatur SAAT, 2017.

Kruger, Thomas. "Law and Wisdom according to Deut. 4:5-8." Dalam Wisdom and Torah: The Reception of 'Torah' in the Wisdom Literature of the Second Temple Period, disunting oleh Bernd U. Schippe dan D. Andrew Teeter, 35-54. Leiden, Boston: Brill, 2013.

Longman, Tremper, dan Raymond B. Dillard. An introduction to the Old Testament. Grand Rapids, Michigan: Zondervan, 2009.

Maiaweng, Peniel CD. "Understanding Of Wisdom In The Book Of Daniel." Jurnal Jaffray 14, no. 1 (2016): 93-108. http://dx.doi.org/10.25278/jj71.v14i1.192.

Marttila, Marko, dan Mika S. Pajunen. "Wisdom, Israel and Other Nations." Journal of Ancient Judaism 3 (2012): 2-26. 
Marttila, Marko, dan Mika S Pajunen. "Wisdom, Israel and Other Nations: Perspectives from the Hebrew Bible, Deuterocanonical Literature, and the Dead Sea Scrolls." Journal of Ancient Judaism 4, no. 1 (2013): 2-26. https://doi.org/10.30965/21967954-00401002.

Matacio, Doug. "Centripetal and 'Centrifugal' Mission: Solomon and Jesus." Journal of Adventist Mission Studies 4, no. 1 (2008): 31-42. https://digitalcommons.andrews.edu/cgi/viewcontent.cgi?referer=https://sc holar.google.com/\&httpsredir $=1 \&$ article $=1098 \&$ context=jams.

Mayes, Andrew DH. "Deuteronomy 4 and the Literary Criticism of Deuteronomy." Journal of Biblical Literature 100, no. 1 (1981): 23-51. https://doi.org/10.2307/3265533.

Merrill, Eugene E. The New American Commentary: Deuteronomy. 4 ed. Nashville, Tennesse: B\&H Publishing Group, 1994.

Moskala, Jiri. "The mission of God's people in the Old Testament." Journal of the Adventist Theological Society 19, no. 1 (2008): 40. https://digitalcommons.andrews.edu/old-testament-pubs/9.

Olson, C. G. What in the World is God Doing? Cedar Knolls, NJ: Global Gospel Publishers, 2003.

Omwenga, R. "Mission to people of other faiths in the Old Testament and Eldoret, Kenya: Some reflections for engaging Muslims within their context." Acta theologica 35, no. 1 (2015): https://hdl.handle.net/10520/EJC172466.

Piper, John. Jadikan Sekalian Bangsa Bersukacita: Supremasi Allah dalam Misi. Disunting oleh Doreen Widjana. Bandung: Lembaga Literatur Baptis, 2003.

Riecker, Siegbert. "Missions In The Hebrew Bible Revisited: Four Theological Trails Instead Of One Confining Concept." Missiology: An International Review, 2016, 1-16.

Sanjaya, V Indra. "Pergulatan Hikmat dalam Kitab Pengkhotbah." Jurnal Orientasi Baru 19, no. 2 (2010): 109-23. https://ejournal.usd.ac.id/index.php/job/article/view/1375/1117.

Siahaan, Harls Evan Rianto. "Hikmat Sebagai Implikasi Pendidikan Kristiani: Refleksi 1 Raja-raja 3:1-15." DUNAMIS: Jurnal Penelitian Teologi dan Pendidikan Kristiani 1, no. 1 (1 Oktober 2016): 15-30. https://doi.org/10.30648/dun.v1i1.99.

Sung, Choi Yong. "Kompetensi Kerjasama Misi Lintas Budaya Misionaris PCK Dengan Pemimpin Gereja Lokal Indonesia." JURNAL LUXNOS 5, no. 2 (2019): 111-26. https://doi.org/10.47304/j1.v5i2.20. 
Welton, DM. "The old testament wisdom (Chokma)." The Biblical World 10, no. 3 (1897):

183-89. https://www.journals.uchicago.edu/doi/pdfplus/10.1086/472129.

Widbin, R. Bryan. "Salvation for People Outside Israel's Covenant?," Through No Fault of Their Own? The Fate of Those Who Have Never Heard. Disunting oleh W. V. Crockett and J. G. Sigountos. Grand Rapids: Baker, 1991.

Wright, Chris. "The Old Testament and Christian Mission." Evangel 14, no. 2 (1996): 37-43. http://biblicalstudies.gospelstudies.org.uk/pdf/evangel/142_037.pdf.

Wright, Christopher J.H. "Truth with a Mission: Reading All Scripture Missiologically." The Southern Baptist Journal of Theology 15, no. 2 (2011): 4-15. 